ISSN: 2302-8556

E-Jurnal Akuntansi Universitas Udayana

Vol.22.3. Maret (2018): 1682-1710

DOI: https://doi.org/10.24843/EJA.2018.v22.i03.p02

\title{
Pengaruh Profitabilitas, Ukuran Perusahaan, Struktur Aset, Risiko Bisnis dan Likuiditas pada Struktur Modal
}

\author{
Ni Putu Nita Septiani ${ }^{1}$ \\ I Gusti Ngurah Agung Suaryana ${ }^{2}$
}

${ }^{1}$ Fakultas Ekonomi dan Bisnis Universitas Udayana (Unud), Bali, Indonesia
email: nitaseptiani401@gmail.com / Tlp: 085338098304
${ }^{2}$ Fakultas Ekonomi dan Bisnis Universitas Udayana (Unud), Bali, Indonesia

\begin{abstract}
ABSTRAK
Setiap perusahaan pasti memiliki tujuan utama yang sama yaitu untuk memaksimumkan nilai perusahaan. Untuk dapat memaksimumkan nilai perusahaan, salah satu cara yang perlu dilakukan perusahaan adalah menghasilkan suatu struktur modal yang optimal. Berdasarkan kajian teori dan hasil penelitian sebelumnya, struktur modal dapat dipengaruhi oleh profitabilitas, ukuran perusahaan, struktur aset, risiko bisnis dan likuiditas. Oleh karena itu, perusahaan harus mempertimbangkan faktor - faktor di atas saat akan menetapkan struktur modalnya agar dapat menghasilkan struktur modal yang optimal. Penelitian ini bertujuan untuk menguji secara empiris pengaruh profitabilitas, ukuran perusahaan, struktur aset, risiko bisnis dan likuiditas pada struktur modal. Penelitian ini dilakukan pada perusahaan property dan real estate yang terdaftar di Bursa Efek Indonesia (BEI) periode 2013-2015, dengan sampel yang diambil sebanyak 27 perusahaan dari total populasi yang berjumlah 48 perusahaan. Sampel dalam penelitian ini ditentukan dengan menggunakan metode purposive sampling. Data dikumpulkan dengan menggunakan metode observasi non partisipan. Teknik analisis data yang digunakan adalah Analisis Regresi Linear Berganda. Berdasarkan hasil analisis disimpulkan bahwa ukuran perusahaan berpengaruh positif pada struktur modal, di mana peningkatan pada ukuran perusahaan akan meningkatkan pula struktur modal. Struktur aset dan likuiditas berpengaruh negatif terhadap struktur modal, di mana peningkatan terhadap struktur aset dan likuiditas akan menurunkan struktur modal. Sedangkan, profitabilitas dan risiko bisnis tidak berpengaruh terhadap struktur modal.
\end{abstract}

Kata kunci: Struktur modal, profitabilitas, ukuran perusahaan, struktur aset, risiko bisnis, likuiditas

\begin{abstract}
Each company must have the same primary goal that is to maximize the value of the company. To be able to maximize the value of the company, one of the ways that companies need to do is produce an optimal capital structure. Based on the study of theory and previous research results, the capital structure can be influenced by profitability, firm size, asset structure, business risk and liquidity. Therefore, companies should consider the above factors when establishing their capital structure in order to produce an optimal capital structure. This study aims to examine empirically the effect of profitability, firm size, asset structure, business
\end{abstract}


risk and liquidity in the capital structure. This research was conducted on the property and real estate company period 2013-2015 listed in Indonesia Stock Exchange, with samples taken as many as 27 companies out of a total population of 48 companies. The sample in this research was determined by purposive sampling method using a criterion. Data were collected using non-participant observation. The data analysis technique used is the Multiple Linear Regression Analysis. Based on the results of the analysis concluded that firm size has a positive effect on capital structure, where the increase in firm size will also increase the capital structure. The structure of assets and liquidity negatively affect the capital structure, where an increase in asset structure and liquidity will decrease the capital structure. Meanwhile, profitability and business risk have no effect on capital structure.

Keywords: Capital structure, profitability, firm size, asset structure, business risk, liquidity

\section{PENDAHULUAN}

Dewasa ini, di tengah era globalisasi yang terjadi di segala bidang, khususnya di bidang perekonomian mengakibatkan peta persaingan di antara setiap perusahaan semakin ketat, sehingga menuntut setiap perusahaan untuk berkembang agar dapat mengikuti arus perkembangan zaman. Upaya tersebut merupakan permasalahan tersendiri bagi suatu perusahaan, karena hal ini menyangkut keputusan pemenuhan dana yang diperlukan oleh perusahaan untuk berkembang. Tuntutan yang sedemikian besar bagi perusahaan untuk berkembang mengikuti arus zaman menyebabkan kebutuhan akan pendanaan ikut meningkat, sehingga perusahaan kemungkinan akan menggunakan sumber pendanaan eksternal dikarenakan sangat mustahil apabila hanya menggunakan sumber pendanaan internal untuk memenuhi seluruh kebutuhan dana untuk operasi perusahaan. Oleh karena suatu perusahaan pasti akan menggunakan sumber pendanaan internal maupun eksternal, maka penting bagi perusahaan untuk memadukan sumber-sumber pendanaan yang akan digunakan untuk operasionalnya secara tepat agar dapat menghasilkan struktur modal yang optimal bagi perusahaan. 
ISSN: 2302-8556

E-Jurnal Akuntansi Universitas Udayana

Vol.22.3. Maret (2018): 1682-1710

Struktur modal didefinisikan sebagai perimbangan atau perbandingan antara jumlah utang jangka panjang dengan modal sendiri (Riyanto, 2001:22). Struktur modal yang optimal adalah struktur modal yang diperkirakan akan menghasilkan biaya modal rata-rata tertimbang yang paling rendah sehingga akan memaksimumkan nilai perusahaan (Widyaningrum, 2015). Pada umumnya, memaksimumkan nilai perusahaan merupakan tujuan utama setiap perusahaan, dikarenakan nilai perusahaan yang tinggi dapat meningkatkan kemakmuran bagi para pemegang saham, dapat menjadi pondasi yang kuat bagi perusahaan untuk menjalankan operasinya, dan mampu mendatangkan keuntungan optimal bagi perusahaan (Nadzirah, 2016). Hal ini menunjukkan bahwa penentuan struktur modal merupakan masalah yang penting bagi setiap perusahaan.

Pentingnya masalah penentuan struktur modal bagi suatu perusahaan, membuat seorang manajer sebaiknya mengetahui faktor apa saja yang mempengaruhi struktur modal suatu perusahaan. Salah satu faktor yang mempengaruhi struktur modal adalah profitabilitas. Riyanto (2001:35) menyatakan bahwa profitabilitas menunjukkan perbandingan antara laba dengan aset atau ekuitas suatu perusahaan yang menghasilkan laba tersebut. Dengan kata lain, profitabilitas adalah kemampuan perusahaan untuk menghasilkan laba selama periode tertentu. Profitabilitas dapat diukur menggunakan tiga proksi, yaitu profit margin, return on asset (ROA) dan return on equity $(\mathrm{ROE})$.

Brigham dan Houston (2006) menyatakan bahwa perusahaan dengan tingkat pengembalian yang tinggi atas investasi cenderung menggunakan utang yang relatif 
kecil. Oleh karena itu, perusahaan yang profitable cenderung mempunyai utang yang lebih kecil dibandingkan perusahaan yang tidak profitable dikarenakan memilih menggunakan laba di tahan untuk mendanai operasinya daripada menggunakan utang. Hal ini sesuai dengan pecking order theory yang menjelaskan tentang urutan pendanaan yang disenangi perusahaan. Penelitian Bauer (2004), Chen, dkk (2009), Nadzirah (2016), dan Angelina (2016) menyatakan bahwa profitabilitas berpengaruh negatif dan signifikan terhadap struktur modal. Secara khusus, Salawo (2009) menyatakan bahwa profitabilitas berkorelasi negatif dengan utang jangka panjang, sehingga menunjukkan hubungan negatif antara struktur modal dengan profitabilitas. Hasil ini berbeda dengan penelitian Rafique (2011), dan Widyaningrum (2015) yang menyatakan profitabilitas tidak berpengaruh terhadap struktur modal. Selain itu, penelitian Titman and Wessel (1988) dan Putri (2012) juga menunjukkan hasil yang berbeda, di mana profitabilitas berpengaruh positif dan signifikan terhadap struktur modal. Hal ini sesuai dengan signaling theory yang menyatakan bahwa utang yang lebih besar mengindikasikan kinerja perusahaan yang baik, sehingga manajer dan investor lebih yakin terhadap masa depan perusahaan (Lim, 2012).

Faktor lain yang mempengaruhi struktur modal adalah ukuran perusahaan. Riyanto (2001) menjelaskan bahwa ukuran perusahaan merupakan besar kecilnya perusahaan dilihat dari besarnya nilai equity, nilai perusahaan, ataupun hasil nilai total aset dari suatu perusahaan. Ariyanto (2002) mengatakan bahwa besar kecilnya ukuran suatu perusahaan akan berpengaruh terhadap struktur modal, di mana semakin besar suatu perusahaan, maka semakin besar pula dana yang dibutuhkan perusahaan 
ISSN: 2302-8556

E-Jurnal Akuntansi Universitas Udayana

Vol.22.3. Maret (2018): 1682-1710

untuk melakukan investasinya. Hal ini dikarenakan perusahaan besar membutuhkan dana yang besar pula untuk menunjang operasionalnya dan salah satu alternatif pemenuhannya adalah dengan pendanaan eksternal. Hal ini sesuai dengan pecking order theory yang menyebutkan bahwa suatu perusahaan memilih alternatif penggunaan sumber dana eksternal saat sumber dana internal tidak cukup untuk membiayai operasional perusahaan. Penelitian Defia Riasita (2014), Nadzirah (2016) dan Angelina (2016) menyatakan bahwa ukuran perusahaan berpengaruh positif dan signifikan terhadap struktur modal. Hasil ini berbeda dengan penelitian Titman and Wessels (1988) dan Arief Rahman (2013) yang menyatakan ukuran perusahaan tidak berpengaruh terhadap struktur modal.

Struktur aset juga menjadi faktor yang mempengaruhi struktur modal. Struktur aset menggambarkan sebagian jumlah aset yang dapat dijadikan jaminan. Lim (2012) menyatakan bahwa perusahaan dengan proporsi aset tetap yang tinggi memiliki kemampuan yang lebih besar untuk melunasi utangnya, sehingga memiliki lebih banyak kesempatan untuk memperoleh utang. Hal ini dikarenakan karena aset tetap yang ada dapat digunakan sebagai jaminan utang oleh perusahaan. Jadi, dapat dikatakan struktur aset dapat digunakan untuk menentukan seberapa besar utang jangka panjang yang dapat digunakan berkaitan dengan jumlah jaminan yang dimiliki dan hal ini akan berpengaruh terhadap penentuan besarnya struktur modal perusahaan. Penelitian Lim (2012) dan Widyaningrum (2015) menyatakan bahwa struktur aset berpengaruh positif dan signifikan terhadap struktur modal. Namun, Riyanto dalam Defia Riasita (2014) menyatakan bahwa perusahaan yang sebagian 
besar modalnya tertanam dalam aset tetap akan mengutamakan pemenuhan modalnya dari modal yang permanen, yaitu modal sendiri sedangkan utang sifatnya hanya sebagai pelengkap. Dengan demikian, semakin tinggi struktur aset, maka penggunaan modal sendiri akan semakin tinggi atau dengan kata lain struktur modalnya akan semakin rendah. Hal ini didukung oleh penelitian Sayilgan (2006) dan Arief Rahman (2013) yang menyatakan struktur aset berpengaruh negatif terhadap struktur modal.

Faktor berikutnya yang mempengaruhi struktur modal adalah risiko bisnis. Risiko bisnis adalah ketidakpastian yang dihadapi perusahaan dalam menjalankan kegiatan bisnisnya. Dalam suatu perusahaan, risiko bisnis meningkat jika menggunakan utang yang tinggi. Brigham dan Houston (2006) menyatakan perusahaan yang memiliki risiko bisnis tinggi, akan meningkatkan penggunaan utang sebagai sumber pendanaan. Hal ini didukung oleh penelitian Ervina (2011) yang menyatakan risiko bisnis berpengaruh positif terhadap struktur modal. Hal ini berbeda dengan penelitian Bayless dan Diltz (1994) dan Alnajjar (2015) yang menemukan hubungan negatif antara risiko bisnis dengan struktur modal. Hal ini dikarenakan semakin besar risiko bisnis perusahaan, penggunaan utang yang besar akan mempersulit perusahaan dalam mengembalikan utang mereka sehingga para kreditur ragu-ragu untuk memberikan utang. Selain itu, hasil berbeda ditemukan dalam penelitian Seftianne dan Handayani (2011) dan Erosvitha (2016) dimana risiko bisnis tidak berpengaruh terhadap struktur modal.

Likuiditas juga dapat mempengaruhi penentuan struktur modal. Likuiditas merupakan kemampuan suatu perusahaan untuk memenuhi kewajiban keuangannya 
ISSN: 2302-8556

E-Jurnal Akuntansi Universitas Udayana

Vol.22.3. Maret (2018): 1682-1710

dalam jangka pendek atau yang segera jatuh tempo. Oleh karena itu, perusahaan yang mempunyai likuiditas tinggi cenderung akan menurunkan total utang, sehingga struktur modal ikut menjadi menurun. Selain itu, perusahaan dengan likuiditas tinggi, akan lebih senang menggunakan sumber dana internal, seperti laba ditahan sebelum menggunakan sumber dana eksternal, seperti utang atau menerbitkan saham baru. Hal ini sesuai dengan pecking order theory yang menjelaskan urutan pendanaan yang disenangi oleh perusahaan. Penelitian Arief Rahman (2013) dan Defia Riasita (2014) menyatakan bahwa likuiditas berpengaruh negatif terhadap struktur modal. Hasil ini berbeda dengan penelitian Margaretha dan Ramadhan (2011), Seftianne dan Handayani (2011) yang menyatakan likuiditas tidak berpengaruh terhadap struktur modal.

Penelitian ini dilaksanakan pada perusahaan property dan real estate karena berdasarkan observasi awal pada perusahaan ini terdapat ketidak konsistenan antara hasil observasi dengan teori yang digunakan. Sebagai contoh profitabilitas pada 2013 sebesar 0,074 dan pada 2014 mengalami penurunan sebesar 0,004 menjadi 0,070 yang diikuti dengan penurunan struktur modal dari sebesar 0,871 pada 2013 menjadi 0,773 pada 2014. Keadaan ini tidak sesuai dengan pecking order theory yang menyatakan bahwa perusahaan dengan tingkat pengembalian yang tinggi cenderung menggunakan utang yang relatif kecil. Kemudian, ukuran perusahaan pada 2013 sebesar 28,956 meningkat menjadi sebesar 29,081 pada tahun 2014 yang diikuti dengan penurunan struktur modal dari sebesar 0,871 pada 2013 menjadi 0,773 pada 2014. Keadaan ini tidak sesuai dengan pecking order theory yang menyatakan bahwa 
perusahaan yang bertumbuh dengan cepat membutuhkan modal yang besar sehingga akan meminjam lebih banyak (Nanok, 2008).

Selain itu, risiko bisnis pada 2014 sebesar 0,030 meningkat sebesar 0,001 menjadi 0,031 pada 2015 yang diikuti dengan peningkatan struktur modal dari sebesar 0,773 pada 2014 menjadi 0,816 pada 2015. Keadaan ini tidak sesuai dengan trade-off theory yang menyatakan bahwa penggunaan utang yang semakin banyak akan semakin meningkatkan risiko yang ditanggung perusahaan, sehingga perusahaan dengan risiko tinggi seharusnya mengurangi penggunaan utangnya. Hal serupa terjadi pada likuiditas di mana pada 2014 sebesar 1,991 meningkat menjadi sebesar 2,125 pada 2015 yang diikuti dengan peningkatan struktur modal dari sebesar 0,773 pada 2014 menjadi 0,816 pada 2015. Hal ini tidak sesuai dengan pecking order theory yang menjelaskan bahwa perusahaan yang memiliki likuiditas tinggi akan cenderung memilih menggunakan dana internalnya terlebih dahulu untuk membiayai operasinya sebelum menggunakan pembiayaan eksternal.

Profitabilitas adalah kemampuan perusahaan menghasilkan laba. Menurut Brigham dan Houston (2006) perusahaan dengan tingkat pengembalian yang tinggi atas investasi menggunakan utang yang relatif kecil. Selain itu, penelitian yang dilakukan oleh Myers dan Majluf (1984) menunjukkan bahwa profitabilitas yang bisa diukur dengan Return on Asset (ROA) berpengaruh negatif terhadap utang, dimana perusahaan dengan tingkat pengembalian yang tinggi atas investasi akan menggunakan utang yang relatif kecil. Tingkat pengembalian yang tinggi memungkinkan untuk membiayai sebagian besar kebutuhan pendanaan dengan dana 
ISSN: 2302-8556

E-Jurnal Akuntansi Universitas Udayana

Vol.22.3. Maret (2018): 1682-1710

yang dihasilkan secara internal. Semakin tinggi profitabilitas menunjukkan bahwa laba yang diperoleh perusahaan juga tinggi. Peningkatan profitabilitas akan meningkatkan laba ditahan, sesuai dengan pecking order theory yang mempunyai preferensi pendanaan pertama dengan dana internal berupa laba ditahan, sehingga komponen modal sendiri semakin meningkat. Dengan meningkatnya modal sendiri, maka rasio utang menjadi menurun (dengan asumsi utang relatif tetap).

Hal ini didukung oleh penelitian Bauer (2004), Chen, dkk (2009), Wahyuni dan Suryantini (2014), Dewi dan Badjra (2014), Nadzirah (2016) dan Angelina (2016) menyatakan bahwa profitabilitas berpengaruh negatif terhadap struktur modal. Berdasarkan uraian tersebut, maka hipotesis yang diajukan adalah sebagai berikut:

$\mathrm{H}_{1}$ : Profitabilitas berpengaruh negatif pada struktur modal

Besar kecilnya ukuran suatu perusahaan akan berpengaruh terhadap struktur modal, semakin besar perusahaan maka semakin besar pula dana yang dibutuhkan perusahaan untuk melakukan investasinya (Ariyanto, 2002). Semakin besar ukuran suatu perusahaan, kecenderungan menggunakan modal eksternal juga semakin besar karena perusahaan besar membutuhkan dana yang besar pula untuk menunjang operasionalnya, dan salah satu alternatif pemenuhannya adalah dengan modal eksternal apabila modal sendiri sudah tidak mencukupi. Hal ini sesuai dengan pecking order theory yang menjelaskan bahwa kesempatan bertumbuh perusahaan berpengaruh terhadap struktur modal (Seftianne dan Handayani, 2011) dan 
perusahaan yang bertumbuh dengan cepat membutuhkan modal yang besar dan memiliki kesempatan meminjam lebih banyak (Nanok, 2008).

Hal ini didukung oleh penelitian Mustafa (2011), Wahyuni dan Suryantini (2014), Widyaningrum (2015) dan Nadzirah (2016) menyatakan bahwa ukuran perusahaan berpengaruh positif terhadap struktur modal. Berdasarkan uraian tersebut, maka hipotesis yang diajukan adalah sebagai berikut:

$\mathrm{H}_{2}$ : Ukuran perusahaan berpengaruh positif pada struktur modal

Struktur aset menggambarkan sebagian jumlah aset yang dapat dijadikan jaminan. Brigham dan Houston (2006) menyatakan bahwa perusahaan yang memiliki aset memadai atau asetnya memiliki perbandingan aset tetap jangka panjang lebih besar akan menggunakan utang lebih banyak karena aset tetap yang ada dapat digunakan sebagai jaminan utang. Jadi, dapat dikatakan struktur aset dapat digunakan untuk menentukan seberapa besar utang jangka panjang yang dapat digunakan berkaitan dengan jumlah jaminan yang dimiliki dan hal ini akan berpengaruh terhadap penentuan besarnya struktur modal perusahaan. Hal ini sesuai dengan tradeoff theory yang menyatakan bahwa aset tetap dapat dijadikan jaminan untuk melakukan pinjaman baru berupa utang (Rajan dan Zingales, 1995), sehingga perusahaan dengan aset tetap tinggi berpeluang lebih besar untuk mendapatkan utang dengan menjaminkan aset tetapnya.

Selain itu, perusahaan yang memiliki banyak aset tetap menunjukkan bahwa perusahaan tersebut memiliki nilai likuidasi yang tinggi sehingga kreditur dapat 
ISSN: 2302-8556

E-Jurnal Akuntansi Universitas Udayana

Vol.22.3. Maret (2018): 1682-1710

menerima kembali dana mereka apabila perusahaan dilikuidasi. Hal inilah yang menjadi motivasi bagi kreditur untuk menyetujui kredit, sehingga perusahaan mudah mendapatkan pinjaman/utang. Hal ini didukung oleh penelitian Widyaningrum (2015) yang menyatakan struktur aset berpengaruh positif terhadap struktur modal. Selain itu, penelitian oleh Margaretha dan Ramadhan (2010), Mustafa (2011), dan Lim (2012) memperoleh hasil yang sama mengenai hubungan struktur aset dengan struktur modal. Berdasarkan uraian tersebut, maka hipotesis yang diajukan sebagai berikut:

$\mathrm{H}_{3}$ : $\quad$ Struktur aset berpengaruh positif pada struktur modal

Risiko bisnis adalah ketidakpastian yang dihadapi perusahaan dalam menjalankan kegiatan bisnisnya. Penggunaan utang sebagai modal untuk meningkatkan aset atau menjalankan operasi perusahaan tidak sembarangan diambil dengan memperhatikan risiko bisnis yang ditanggung perusahaan. Perusahaan yang memiliki risiko tinggi akan membuat para kreditur ragu-ragu untuk memberikan kredit, karena besar kemungkinan perusahaan tidak mampu mengembalikan utang dan mengalami kebangkrutan. Oleh karena itu, perusahaan yang memiliki risiko bisnis yang tinggi cenderung akan mengurangi penggunaan utang untuk menghindari kebangkrutan. Hal ini sesuai dengan trade-off theory yang menjelaskan bahwa penggunaan utang yang semakin banyak akan semakin meningkatkan risiko yang ditanggung perusahaan. Bahkan, Titman dan Wessels (1988) menyatakan bahwa perusahaan dengan risiko yang tinggi seharusnya menggunakan utang yang lebih sedikit untuk menghindari kebangkrutan. 
Hal ini didukung oleh penelitian Bayless dan Dilltz (1994) dan Alnajjar (2015) yang menemukan hubungan negatif antara risiko bisnis dengan utang. Hal ini dikarenakan semakin besar risiko bisnis perusahaan, penggunaan utang yang besar akan mempersulit perusahaan dalam mengembalikan utang mereka sehingga para kreditur ragu-ragu untuk memberikan utang. Berdasarkan uraian tersebut, maka hipotesis yang diajukan sebagai berikut:

$\mathrm{H}_{4}$ : Risiko bisnis berpengaruh negatif pada struktur modal

Rasio likuiditas digunakan untuk mengukur kemampuan perusahaan untuk memenuhi kewajiban jangka pendeknya (Van Horne dan Wachowicz, 1998). Suatu perusahaan yang likuiditasnya meningkat, lebih memilih untuk tidak menggunakan pinjaman (Joni dan Lina, 2010). Hal ini sesuai dengan pecking order theory yang menjelaskan bahwa perusahaan yang memiliki likuiditas tinggi akan cenderung tidak menggunakan pembiayaan dari utang, dikarenakan perusahaan dengan likuiditas yang tinggi mempunyai dana internal yang besar sehingga perusahaan tersebut akan lebih memilih menggunakan dana internalnya terlebih dahulu untuk membiayai operasinya sebelum menggunakan pembiayaan eksternal. Selain itu, Titman dan Wessel (1988) menyatakan bahwa, pecking order theory berpendapat bahwa perusahaan dengan kelebihan kas akan menggunakan kas tersebut untuk mengurangi utang. Hal ini menunjukkan perusahaan dengan likuiditas yang tinggi akan membuat perusahaan membayar utang-utangnya, sehingga akan berpengaruh pada menurunnya struktur modal. 
ISSN: 2302-8556

E-Jurnal Akuntansi Universitas Udayana

Vol.22.3. Maret (2018): 1682-1710

Penelitian Arief Rahman (2013) menyatakan bahwa likuiditas berpengaruh negatif terhadap struktur modal. Hasil penelitian ini didukung oleh penelitian Defia Riasita (2014), Merta Dewi dan Badjra (2014) yang menunjukkan bahwa terdapat hubungan negatif antara likuiditas dengan struktur modal. Berdasarkan uraian tersebut, maka hipotesis yang diajukan sebagai berikut:

$\mathrm{H}_{5}$ : Likuiditas berpengaruh negatif pada struktur modal

\section{METODE PENELITIAN}

Penelitian ini menggunakan pendekatan kuantitatif yang berbentuk asosiatif. Berdasarkan permasalahan yang telah dikemukakan, kajian teoritis, dan tinjauan penelitian terdahulu, maka desain penelitian ini dapat digambarkan sebagai berikut:

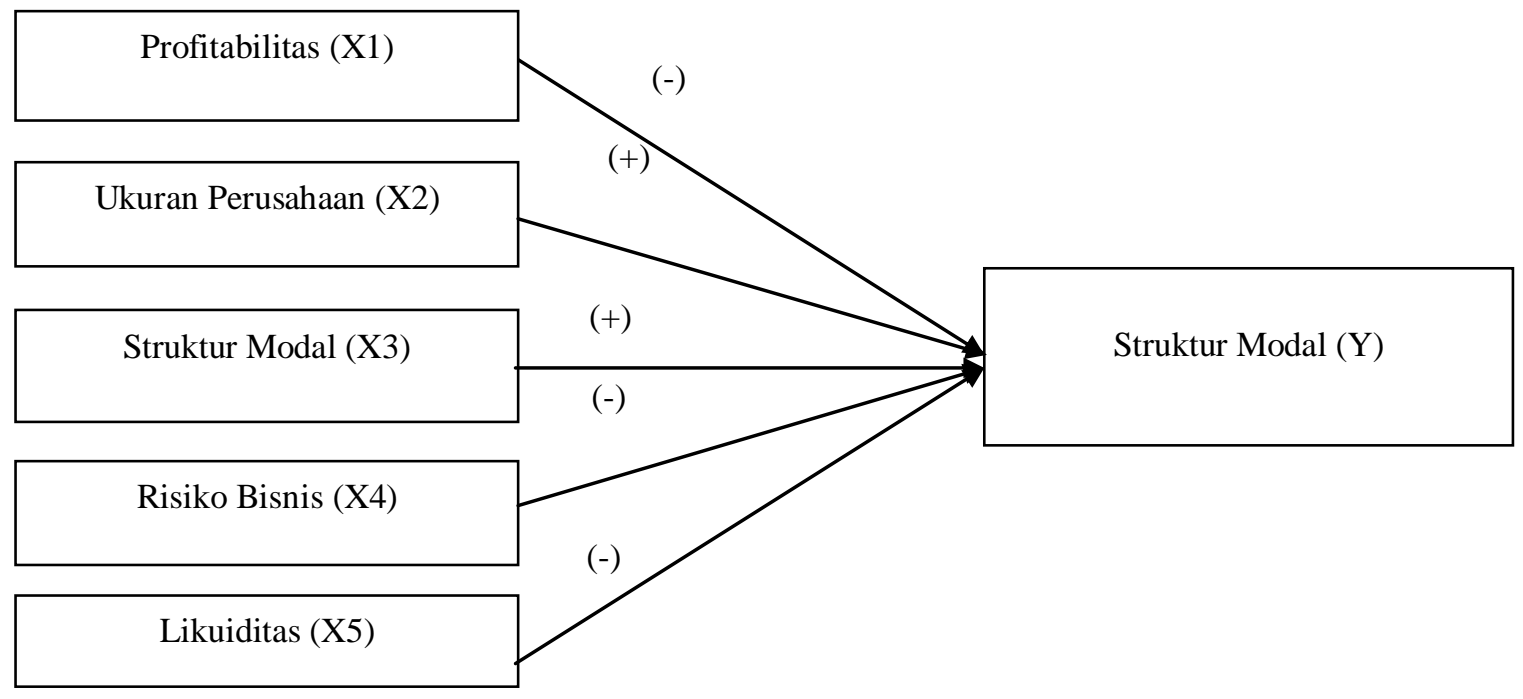

Gambar 1. Desain Penelitian

Sumber: Data diolah, 2017 
Penelitian ini mengambil sampel perusahaan-perusahaan Property dan Real Estate yang terdaftar di Bursa Efek Indinesia (BEI). Penelitian ini dilakukan dengan mengambil data dari www.idx.co.id periode 2013-1015. Objek penelitian dalam penelitian ini adalah Pengaruh Profitabilitas, Ukuran Perusahaan, Struktur Aset, Risiko Bisnis dan Lukuiditas pada Struktur Modal pada Perusahaan Sub Sektor Property dan Real Estate yang Terdaftar di Bursa Efek Indonesia periode 2013-2015. Data diperoleh dari laporan tahunan (annual report) perusahaan yang didapatkan melalui situs www.idx.co.id.

Variabel terikat dipenelitian ini adalah struktur modal perusahaan. Riyanto (2001:22) menyatakan bahwa struktur modal adalah pembelanjaan permanen di mana mencerminkan perimbangan antara utang jangka panjang dengan modal sendiri. Pada penelitian ini, struktur modal diproksikan dengan menggunakan Debt Equity Ratio (DER). DER mencerminkan sampai sejauh mana modal perusahaan dapat menutupi utang kepada pihak luar.

Variabel bebas dipenelitian ini adalah profitabilitas, ukuran perusahaan, struktur aset, risiko bisnis dan likuiditas. Profitabilitas $\left(\mathrm{X}_{1}\right)$ merupakan rasio yang menunjukkan kemampuan suatu perusahaan dalam memperoleh laba. Ukuran Perusahaan $\left(\mathrm{X}_{2}\right)$ merupakan besar kecilnya perusahaan dilihat dari besarnya nilai equity, nilai perusahaan, ataupun hasil nilai total aktiva dari suatu perusahaan (Riyanto, 2001). Pada penelitian ini, ukuran perusahaan diukur dengan memproksikan total aset perusahaan dengan nilai logaritma natural (Ln Total Aset) (Lim, 2012 dan Nadzirah, 2016). Struktur Aset $\left(\mathrm{X}_{3}\right)$ menggambarkan sebagian 
ISSN: 2302-8556

E-Jurnal Akuntansi Universitas Udayana

Vol.22.3. Maret (2018): 1682-1710

jumlah asset yang dapat dijadikan jaminan. Risiko Bisnis $\left(\mathrm{X}_{4}\right)$ merupakan ketidakpastian yang dihadapi perusahaan dalam menjalankan kegiatan bisnisnya. Likuiditas $\left(\mathrm{X}_{5}\right)$ merupakan kemampuan suatu perusahaan untuk memenuhi kewajiban keuangannya dalam jangka pendek atau yang segera jatuh tempo.

Jenis data yang digunakan dalam penelitian ini adalah data kuantitatif. Data kuantitatif dalam penelitian ini yaitu data laporan tahunan (annual report) perusahaan property dan real estate yang terdaftar di Bursa Efek Indonesia periode 2013-2015 yang diperoleh melalui website www.idx.co.id. Sumber data yang digunakan dalam penelitian ini adalah data sekunder. Sumber yang digunakan dalam penelitian ini adalah sumber data sekunder yang diperoleh dari laporan tahunan (annual report) perusahaan property dan real estate yang terdaftar di Bursa Efek Indonesia periode 2013-2015.

Populasi dari penelitian ini adalah semua perusahaan property dan real estate yang terdaftar di Bursa Efek Indonesia (BEI) pada tahun 2013, 2014, dan 2015. Metode penentuan sampel yang digunakan dalam penelitian ini adalah metode purposive sampling. Metode pengumpulan data yang digunakan dalam penelitian ini adalah metode observasi nonpartisipan. Dalam penelitian ini, data dikumpul dengan cara mencatat, mengamati, mempelajari serta menganalisis data-data dalam bentuk laporan tahunan (annual report) perusahaan property dan real estate yang terdaftar di Bursa Efek Indonesia untuk periode 2013-2015 yang diperoleh dengan mengakses Bursa Efek Indonesia melalui www.idx.co.id. 


\section{Tabel 1.}

\section{Hasil Seleksi Sampel}

\begin{tabular}{cllllcc}
\hline No & \multicolumn{5}{c}{ Kriteria } & Jumlah \\
\hline 1 & $\begin{array}{l}\text { Perusahaan yang terdaftar } \\
2013,2014,2015\end{array}$ & Bursa & Efek Indonesia pada tahun & 48 \\
2 & $\begin{array}{l}\text { Perusahaan yang keluar atau delisting dari Bursa Efek Indonesia periode } \\
\text { penelitian }\end{array}$ & (21) \\
\hline \multicolumn{6}{c}{ Jumlah sampel penelitian selama periode pengamatan } & 81 \\
\hline
\end{tabular}

Sumber: Data diolah, 2017

Penelitian ini menggunakan teknik analisis regresi linier berganda. Teknik ini

digunakan untuk mengetahui pengaruh antara enam variabel dalam penelitian, yaitu

Profitabilitas, Ukuran Perusahaan, Struktur Aset, Risiko Bisnis, dan Likuiditas terhadap Struktur Modal pada perusahaan property dan real estate yang terdaftar di Bursa Efek Indonesia periode 2013-2015. Persamaan regresi dalam penelitian ini adalah.

$$
Y=\alpha+\beta_{1} X_{1}+\beta_{2} X_{2}+\beta_{3} X_{3}+\beta_{4} X_{4}+\beta_{5} X_{5}+\varepsilon
$$

Keterangan:

$\mathrm{Y} \quad=$ Struktur Modal

$\alpha \quad=$ Konstanta

$\beta_{1}-\beta_{5}=$ Koefisien Regresi

$\mathrm{X}_{1} \quad=$ Profitabilitas

$\mathrm{X}_{2} \quad=$ Ukuran Perusahaan

$\mathrm{X}_{3}=$ Struktur Aset

$\mathrm{X}_{4} \quad=$ Risiko Bisnis

$\mathrm{X}_{5} \quad=$ Likuiditas

$\varepsilon \quad=$ Error

\section{HASIL DAN PEMBAHASAN}

Pengujian statistik deskriptif dilakukan untuk mengetahui gambaran umum tentang sampel. Deskripsi sampel berupa nilai tertinggi dari profitabilitas, ukuran perusahaan, struktur aset, risiko bisnis dan likuiditas; nilai terendah dari profitabilitas, ukuran 
ISSN: 2302-8556

E-Jurnal Akuntansi Universitas Udayana

Vol.22.3. Maret (2018): 1682-1710

perusahaan, struktur aset, risiko bisnis dan likuiditas; serta nilai rata-rata dari profitabilitas, ukuran perusahaan, struktur aset, risiko bisnis, dan likuiditas dalam setiap tahun selama periode 2013-2015. Hasil analisis deskriptif dapat dilihat pada Tabel 2 berikut ini:

Tabel 2.

Hasil Statistik Deskriptif

\begin{tabular}{ccccccc}
\hline No & Variabel & N & Min & Max & Mean & Std. Dev \\
\hline 1 & Profitabilitas & 81 & $-0,088$ & 0,316 & 0,064 & 0,068 \\
2 & Ukuran Perusahaan & 81 & 25,773 & 31,352 & 29,068 & 1,458 \\
3 & Struktur Aset & 81 & 0,136 & 1,008 & 0,602 & 0,226 \\
4 & Risiko Bisnis & 81 & 0,004 & 0,113 & 0,028 & 0,023 \\
5 & Likuiditas & 81 & 0,325 & 6,913 & 2,015 & 1,351 \\
6 & Struktur Modal & 81 & 0,083 & 2,242 & 0,820 & 0,465 \\
\hline \multicolumn{2}{l}{ Sumber: Data diolah, 2017 } &
\end{tabular}

Berdasarkan statistik deskriptif yang ditunjukkan pada Tabel 2 dengan jumlah data (N) sebanyak 81 dengan periode waktu tiga tahun (2013-2015) menunjukkan nilai rata-rata (mean) struktur modal 0,820 artinya proporsi modal sendiri lebih besar dari utang dalam industri property dan real estate. Nilai terendah (minimum) dari struktur modal adalah 0,083, sedangkan nilai tertinggi (maksimum) dari struktur modal adalah 2,242. Sedangkan, standar deviasi sebesar 0,465 dimana lebih kecil dari nilai rata-rata, menunjukkan bahwa adanya variasi data yang kecil pada struktur modal dan kesenjangan antara nilai minimum dan maksimum relatif rendah.

Uji statistik yang digunakan untuk menguji normalitas residual dalam penelitian ini adalah metode one - sample Kolmogorov-Smirnov test. Suatu model dikatakan normal bila signifikansi unstandardized residual lebih besar dari 0,05, 
sedangkan bila signifikansi unstandardized residual lebih kecil dari 0,05 maka model tidak berdistribusi normal. Hasil uji normalitas dapat dilihat pada Tabel 3 berikut ini:

Tabel 3. Hasil Uji Normalitas

\begin{tabular}{ccc}
\hline Model & N & Asymp.sig (2-tailed) \\
\hline Persamaan Regresi 1 & 81 & 0,200 \\
\hline Sumber: Data diolah, 2017 & &
\end{tabular}

Berdasarkan pada Tabel 3 dapat dilihat hasil uji normalitas menunjukkan nilai Asymp.Sig (2-tailed) adalah 0,200. Nilai Asymp.Sig (2-tailed) tersebut lebih besar dari 0,05. Hal ini menunjukkan bahwa semua data pada model regresi telah berdistribusi normal dan layak digunakan untuk analisis lebih lanjut.

Uji multikolinearitas dimaksudkan untuk membuktikan atau menguji ada atau tidaknya hubungan yang linear antara variabel bebas yang satu dengan variabel bebas lainnya. Adapun hasil uji multikolinearitas dapat dilihat pada Tabel 4 berikut ini.

\section{Tabel 4.}

Hasil Uji Multikoleniaritas

\begin{tabular}{lllll}
\hline Model & Variabel & Tolerance & VIF & Ket \\
\hline Regresi 1 & Profitabilitas & 0,918 & 1,090 & Bebas Multikoleniaritas \\
& Ukuran Perusahaan & 0,917 & 1,090 & Bebas Multikoleniaritas \\
& Struktur Aset & 0,594 & 1,684 & Bebas Multikoleniaritas \\
& Risiko Bisnis & 0,950 & 1,052 & Bebas Multikoleniaritas \\
& Likuiditas & 0,617 & 1,620 & Bebas Multikoleniaritas \\
\hline
\end{tabular}

Sumber: Data diolah, 2017

Berdasarkan Tabel 4 terlihat nilai VIF (Varian Inflatation Factor) dari setiap variabel bebas baik variabel profitabilitas, ukuran perusahaan, struktur aset, risiko bisnis dan likuiditas $<10$ dan nilai Tolerance $>0,1$. Hal ini menunjukkan bahwa model tidak menggandung gejala multikolinearitas, artinya setiap variabel bebas tidak memiliki kolerasi linear. 
ISSN: 2302-8556

E-Jurnal Akuntansi Universitas Udayana

Vol.22.3. Maret (2018): 1682-1710

Uji heteroskedastisitas bertujuan menguji apakah dalam model regresi terjadi ketidaksamaan varian dari residual satu pengamatan ke pengamatan yang lain. Untuk mendeteksi ada atau tidaknya gejala heteroskedastisitas digunakan model glejser. Adapun hasil pengujian heteroskedastisitas dapat dilihat pada Tabel 5 berikut ini:

\section{Tabel 5.}

Hasil Uji Heteroskedastisitas

\begin{tabular}{llll}
\hline Model & Variabel & $\begin{array}{l}\text { Sig. } \\
\text { (2-tailed) }\end{array}$ & Keterangan \\
\hline Regresi 1 & Profitabilitas & 0,166 & Bebas Heteroskedastisitas \\
& Ukuran Perusahaan & 0,081 & Bebas Heteroskedastisitas \\
& Struktur Aset & 0,860 & Bebas Heteroskedastisitas \\
& Risiko Bisnis & 0,393 & Bebas Heteroskedastisitas \\
& Likuiditas & 0,821 & Bebas Heteroskedastisitas \\
\hline
\end{tabular}

Sumber: Data sekunder diolah, 2017

Berdasarkan Tabel 5 dapat dilihat bahwa seluruh variabel memiliki nilai Sig.

$>0,05$. Hal ini menunjukkan bahwa tidak ada gejala heteroskedastisitas yang artinya varian residual antara periode pengamatan satu dengan pengamatan lainnya konstan sepanjang waktu pengamatan.

Uji autokorelasi bertujuan untuk mendeteksi adanya korelasi antara data pada periode sebelumnya $\left(\mathrm{t}_{-1}\right)$ dengan periode saat ini $\left(\mathrm{t}_{1}\right)$. Hasil uji autokorelasi dengan menggunakan Durbin-Watson (D-W) test disajikan pada Tabel 6 berikut ini:

Tabel 6.

Hasil Uji Autokorelasi

\begin{tabular}{cccccc}
\hline Model & R & R Square & $\begin{array}{c}\text { Adjusted R } \\
\text { Square }\end{array}$ & $\begin{array}{c}\text { Std. Error of the } \\
\text { Estimate }\end{array}$ & $\begin{array}{c}\text { Durbin- } \\
\text { Wastson }\end{array}$ \\
\hline 1 & 0,629 & 0,396 & 0,356 & 0,3731293 & 1,860 \\
\hline
\end{tabular}

Sumber: Data diolah, 2017 
Berdasarkan Tabel 6 diperoleh nilai Durbin-Watson (D-W) sebesar 1,860. Nilai tersebut berada diantara $\mathrm{d}_{\mathrm{U}}=1,5109$ dan $4-\mathrm{d}_{\mathrm{U}}=2,140$ atau $1,7720<1,860<$ 2,140 maka tidak ada gejala autokolerasi dalam model regresi.

Analisis regresi linear berganda digunakan untuk mengetahui arah dan besaran pengaruh profitabilitas, ukuran perusahaan, struktur aset, risiko bisnis dan likuiditas pada struktur modal perusahaan property dan real estate di Bursa Efek Indonesia pada tahun 2013-2015. Hasil analisis regresi linear berganda untuk penelitian ini dapat dilihat dalam Tabel 7 berikut ini:

Tabel 7.

Hasil Analisis Regresi Linear Berganda

\begin{tabular}{|c|c|c|c|c|c|c|c|}
\hline & \multirow[t]{2}{*}{ Variabel } & \multicolumn{2}{|c|}{$\begin{array}{l}\text { Unstandardized } \\
\text { Coefficients }\end{array}$} & \multirow{2}{*}{$\begin{array}{c}\begin{array}{c}\text { Standardized } \\
\text { Coefficients }\end{array} \\
\text { Beta }\end{array}$} & \multirow[t]{2}{*}{$\mathbf{T}$} & \multirow[t]{2}{*}{ Sig } & \multirow[t]{2}{*}{ Hasil Uji } \\
\hline & & B & $\begin{array}{l}\text { Std. } \\
\text { Error }\end{array}$ & & & & \\
\hline \multirow[t]{10}{*}{1} & (Constant) & $-2,184$ & 0,887 & & $-2,464$ & 0,016 & \\
\hline & Profitabilitas & $-0,825$ & 0,640 & $-0,121$ & $-1,288$ & 0,202 & Ditolak \\
\hline & Ukuran Perusahaan & 0,137 & 0,030 & 0,430 & 4,585 & 0,000 & Diterima \\
\hline & Struktur Aset & $-0,866$ & 0,240 & $-0,421$ & $-3,616$ & 0,001 & Ditolak \\
\hline & Risiko Bisnis & $-0,697$ & 1,855 & $-0,035$ & $-0,375$ & 0,708 & Ditolak \\
\hline & Likuiditas & $-0,191$ & 0,039 & $-0,554$ & $-4,853$ & 0,000 & Diterima \\
\hline & R Square & 0,396 & & & & & \\
\hline & Adjusted R Square & 0,356 & & & & & \\
\hline & F Hitung & 9,830 & & & & & \\
\hline & Sig. F Hitung & 0,000 & & & & & \\
\hline
\end{tabular}

Sumber: Data diolah, 2017

Koefisien determinasi $\left(\mathrm{R}^{2}\right)$ mengukur seberapa jauh variasi variabel dependen dapat dijelaskan oleh variabel independennya. Pada Tabel 7 memperlihatkan besarnya nilai Adjusted $R$ Square adalah 0,356. Artinya 35,6 persen variasi struktur modal dipengaruhi oleh profitabilitas, ukuran perusahaan, struktur aset, risiko bisnis dan likuiditas, sedangkan sisanya sebesar 64,4 persen dipengaruhi oleh faktor-faktor lain yang tidak dimasukkan dalam model regresi. 
ISSN: 2302-8556

E-Jurnal Akuntansi Universitas Udayana

Vol.22.3. Maret (2018): 1682-1710

Nilai sig. $F_{\text {hitung }}=0,000<\alpha=0,05$, menunjukkan bahwa secara statistik variabel independen yaitu profitabilitas, ukuran perusahaan, struktur aset, risiko bisnis dan likuiditas merupakan penjelas yang signifikan pada struktur modal perusahaan property dan real estate yang terdaftar di Bursa Efek Indonesia tahun 2013-2015.

Pengujian hipotesis dapat dilihat dari signifikansi hasil uji t pada Tabel 7 diketahui bahwa nilai koefisien regresi (ß) untuk variabel profitabilitas sebesar $-0,825$ dengan tingkat signifikansi sebesar 0,202 yang berarti lebih besar dari $\alpha=0,05$. Hal ini menunjukkan bahwa variabel profitabilitas secara parsial tidak berpengaruh pada struktur modal perusahaan property dan real estate di BEI tahun 2013-2015. Dengan demikian, hipotesis 1 yang menyatakan profitabilitas berpengaruh negatif pada struktur modal ditolak. Nilai koefisien regresi (ß) untuk variabel ukuran perusahaan sebesar 0,137 dengan tingkat signifikansi sebesar 0,000 yang berarti lebih kecil dari $\alpha$ $=0,05$. Hal ini menunjukkan bahwa variabel ukuran perusahaan secara parsial berpengaruh positif dan signifikan pada struktur modal perusahaan property dan real estate di BEI tahun 2013-2015. Dengan demikian, hipotesis 2 yang menyatakan ukuran perusahaan berpengaruh positif pada struktur modal diterima. Nilai koefisien regresi (B) untuk variabel struktur aset sebesar -0,866 dengan tingkat signifikansi sebesar 0,001 yang berarti lebih kecil dari $\alpha=0,05$. Hal ini menunjukkan bahwa variabel struktur aset secara parsial berpengaruh negatif dan signifikan pada struktur modal perusahaan property dan real estate di BEI tahun 2013-2015. Dengan demikian, hipotesis 3 yang menyatakan struktur aset berpengaruh positif pada 
struktur modal ditolak. Nilai koefisien regresi (ß) untuk variabel risiko bisnis sebesar $-0,697$ dengan tingkat signifikansi sebesar 0,708 yang berarti lebih besar dari $\alpha=$ 0,05. Hal ini menunjukkan bahwa variabel risiko bisnis secara parsial tidak berpengaruh pada struktur modal perusahaan property dan real estate di BEI tahun 2013-2015. Dengan demikian, hipotesis 4 yang menyatakan risiko bisnis berpengaruh negatif pada struktur modal ditolak. Nilai koefisien regresi (ß) untuk variabel likuiditas sebesar -0,191 dengan tingkat signifikansi sebesar 0,000 yang berarti lebih kecil dari $\alpha=0,05$. Hal ini menunjukkan bahwa variabel likuiditas secara parsial berpengaruh negatif dan signifikan pada struktur modal perusahaan property dan real estate di BEI tahun 2013-2015. Dengan demikian, hipotesis 5 yang menyatakan likuiditas berpengaruh negatif pada struktur modal diterima.

Hasil uji statistik menunjukkan bahwa hipotesis 1 ditolak, dimana variabel profitabilitas tidak berpengaruh pada struktur modal. Salah satu penyebab profitabilitas tidak berpengaruh pada struktur modal dikarenakan dalam beberapa tahun terakhir perusahaan pada sub sektor property dan real estate sedang mengalami masa resesi di mana perusahaan menghadapi masalah penurunan pada hasil penjualannya yang akan berdampak pula pada jumlah laba yang diperoleh semakin kecil. Oleh karena itu, kreditur dan investor cenderung berorientasi pada rencana bisnis jangka panjang dengan harapan kondisi perekonomian akan membaik. Implikasinya adalah mereka cenderung mengabaikan tingkat profitabilitas dalam jangka pendek, sehingga profitabilitas tidak berpengaruh pada struktur modal (Defia Riasita, 2014). Hasil penelitian ini sejalan dengan penelitian Rafique (2011), Defia 
ISSN: 2302-8556

E-Jurnal Akuntansi Universitas Udayana

Vol.22.3. Maret (2018): 1682-1710

Riasita (2014), dan Widyaningrum (2015) yang menyatakan profitabilitas tidak berpengaruh terhadap struktur modal.

Hasil uji statistik menunjukkan bahwa hipotesis 2 diterima, di mana variabel ukuran perusahaan berpengaruh positif dan signifikan pada struktur modal. Artinya menunjukkan semakin besar ukuran perusahaan yang dimiliki perusahaan property dan real estate maka semakin besar pula dana eksternal khususnya utang yang digunakan perusahaan, sehingga akan meningkatkan struktur modal. Hal ini sesuai dengan pecking order theory yang menjelaskan bahwa kesempatan bertumbuh perusahaan berpengaruh terhadap struktur modal (Seftianne dan Handayani, 2011) dan perusahaan yang bertumbuh dengan cepat membutuhkan modal yang besar dan memiliki kesempatan meminjam lebih banyak (Nanok, 2008). Hasil penelitian ini sejalan dengan penelitian yang dilakukan Mustafa (2011), Wahyuni dan Suryantini (2014), Widyaningrum (2015) dan Nadzirah (2016) menyatakan bahwa ukuran perusahaan berpengaruh positif terhadap struktur modal.

Hasil uji statistik menunjukkan bahwa hipotesis 3 ditolak, di mana variabel struktur aset berpengaruh negatif dan signifikan pada struktur modal. Artinya semakin tinggi struktur aset perusahaan property dan real estate maka semakin kecil dana eksternal khususnya utang yang digunakan, sehingga akan menurunkan struktur modal. Hal ini sesuai dengan pernyataan Riyanto (2001) yang menyatakan bahwa, sebagian besar perusahaan yang mayoritas dari modalnya tertanam dalam aset tetap akan mengutamakan pemenuhan modalnya dari modal permanen, yaitu modal sendiri sedangkan utang sifatnya hanya sebagai pelengkap. Selain itu, hasil penelitian ini 
mendukung pecking order theory dikarenakan permasalahan utama pecking order theory adalah informasi yang asimetri. Struktur aset merupakan salah satu variabel yang menentukan besar kecilnya masalah asimetri informasi. Ketika perusahaan memiliki proporsi aset tetap yang lebih besar, penilaian asetnya menjadi lebih mudah sehingga permasalahan asimetri informasi menjadi lebih rendah. Dengan demikian, perusahaan akan mengurangi penggunaan hutangnya ketika proporsi aset tetap meningkat. Hal ini terkait dengan kecenderungan bahwa manajemen akan berhati-hati dalam membuat dan menggunakan kebijakan hutang baru, agar kewajiban perusahaan semakin kecil. Hasil penelitian ini sejalan dengan penelitian Sayilgan (2006) dan Arief Rahman (2013) yang menyatakan struktur aset berpengaruh negatif terhadap struktur modal.

Hasil uji statistik menunjukkan bahwa hipotesis 4 ditolak, di mana variabel risiko bisnis tidak berpengaruh pada struktur modal. Risiko bisnis yang dimaksudkan disini adalah ketidakpastian yang dihadapi perusahaan dalam menjalankan kegiatan bisnisnya. Seftianne dan Handayani (2011) menyatakan bahwa, salah satu penyebab risiko bisnis tidak berpengaruh terhadap struktur modal dikarenakan terdapat beberapa investor atau kreditur yang memiliki sifat risk taker sehingga tidak terlalu memperhatikan risiko bisnis suatu perusahaan. Bahkan ada beberapa yang merasa tidak masalah dengan risiko yang tinggi, dikarenakan mereka memiliki kesempatan untuk memperoleh tingkat pengembalian yang lebih besar pada perusahaan tersebut. Hasil penelitian ini sejalan dengan penelitian Saidi (2004), Joni dan Lina (2010), 
ISSN: 2302-8556

E-Jurnal Akuntansi Universitas Udayana

Vol.22.3. Maret (2018): 1682-1710

Seftianne dan Handayani (2011) dan Erosvitha (2016) yang menyatakan bahwa risiko bisnis tidak berpengaruh pada struktur modal.

Hasil uji statistik menunjukkan bahwa hipotesis 5 diterima, di mana variabel likuiditas berpengaruh negatif dan signifikan pada struktur modal. Artinya semakin besar likuiditas yang dimiliki perusahaan property dan real estate maka semakin kecil dana eksternal khususnya utang yang digunakan perusahaan, sehingga akan menurunkan struktur modal. Hal ini sesuai dengan pecking order theory yang menjelaskan bahwa perusahaan yang memiliki likuiditas tinggi akan cenderung tidak menggunakan pembiayaan dari utang, dikarenakan perusahaan dengan likuiditas yang tinggi mempunyai dana internal yang besar sehingga perusahaan tersebut akan lebih memilih menggunakan dana internalnya terlebih dahulu untuk membiayai operasinya sebelum menggunakan pembiayaan eksternal. Selain itu, Titman dan Wessel (1988) menyatakan bahwa, perusahaan dengan kelebihan kas akan menggunakan kas tersebut untuk mengurangi utang. Hal ini menunjukkan perusahaan dengan likuiditas yang tinggi akan membuat perusahaan membayar utang-utangnya, sehingga akan berpengaruh pada menurunnya struktur modal. Hasil penelitian ini sejalan dengan penelitian Arief Rahman (2013), Defia Riasita (2014), Merta Dewi dan Badjra (2014) yang menunjukkan bahwa terdapat hubungan negatif antara likuiditas dengan struktur modal. 


\section{SIMPULAN}

Berdasarkan hasil analisis dan pembahasan yang telah dilakukan, maka dapat ditarik kesimpulan bahwa profitabilitas tidak berpengaruh pada struktur modal perusahaan sub sektor property dan real estate yang terdaftar di Bursa Efek Indonesia periode 2013-2015. Ukuran perusahaan berpengaruh positif pada struktur modal perusahaan sub sektor property dan real estate yang terdaftar di Bursa Efek Indonesia periode 2013-2015. Struktur aset berpengaruh negatif pada struktur modal perusahaan sub sektor property dan real estate yang terdaftar di Bursa Efek Indonesia periode 20132015. Risiko bisnis tidak berpengaruh pada struktur modal perusahaan sub sektor property dan real estate yang terdaftar di Bursa Efek Indonesia periode 2013-2015. Likuiditas berpengaruh negatif pada struktur modal perusahaan sub sektor property dan real estate yang terdaftar di Bursa Efek Indonesia periode 2013-2015.

Berdasarkan hasil penelitian dan simpulan maka saran yang dapat disampaikan bagi manajemen untuk memerhatikan ukuran perusahaan, struktur aset dan tingkat likuiditas yang dimiliki perusahaan dalam menentukan kebijakan struktur modal perusahaan. Bagi calon investor, disarankan sebelum menanamkan modalnya di suatu perusahaan perlu untuk mempertimbangkan struktur modal perusahaan, apakah struktur modal yang ditetapkan tersebut memiliki dampak baik atau buruk bagi perusahaan. Dalam konteks ini, untuk mempertimbangkan dampak dari kebijakan struktur modal, calon investor dapat memerhatikan ukuran perusahaan, struktur aset dan tingkat likuiditas yang dimiliki perusahaan. Bagi peneliti selanjutnya, disarankan agar dapat memperpanjang periode penelitian dan 
ISSN: 2302-8556

E-Jurnal Akuntansi Universitas Udayana

Vol.22.3. Maret (2018): 1682-1710

memperluas ruang wilayah penelitian agar menghasilkan penelitian yang lebih komprehensif.

\section{REFERENSI}

Alnajjar, Mohd. I. M. 2015. Business Risk Impact On Capital Structure: A Case of Jordan Industrial Sector. Global Journal of Management and Business Research, 15 (1), pp: 1-8

Angelina, Kadek I. D., dan I Ketut Mustanda. 2016. Pengaruh Ukuran Perusahaan, Pertumbuhan Penjualan dan Profitabilitas pada Struktur Modal Perusahaan. EJurnal Manajemen Unud, 5 (3), h: 1772-1800

Ariyanto, T. 2002. Pengaruh Struktur Kepemilikan Terhadap Struktur Modal Perusahaan. Jurnal Manajemen Indonesia, 1 (1), h: 64-71

Bauer, Patrik. 2004. Determinants of Capital Struture (Empirical Evidence from the Czech Republic). Czech Journal of Economic and Finance, 5 (4), pp: 2-21

Bayless, Mark E., dan J. David Diltz. 1994. Security Offering and Capital Structure Theory. Journal of Business Finance \& Accounting, 21 (1), pp: 77-91

Brigham, Eugene., dan Joel F. Houston. 2006. Dasar-Dasar Manajemen Keuangan Edisi 10. Jakarta: Salemba Empat

Chen, Jian-Shen, Mei-Ching Chen, Wen-Ju Liao, dan Tsung-Hsien Chen. 2009. Influence of Capital Structure and Operational Risk on Profitability of Life Insurance Industry in Taiwan. Journal of Modelling in Management, 4 (1), pp: 7-18

Dewi, Ni Kadek S. M., dan I. B. Badjra. 2014. Pengaruh Likuiditas, Profitabilitas, Tangibility Assets, Ukuran Perusahaan dan Pajak Terjadap Struktur Modal. EJurnal Manajemen Universitas Udayana, 3 (10), h: 3017-3033

Erosvitha, Cicilia K. L., dan Ni Gusti Putu Wirawati. 2016. Pengaruh Profitabilitas, Set Kesempatan Investasi, Pertumbuhan Penjualan dan Risiko Bisnis pada Struktur Modal. E-Jurnal Akuntansi Universitas Udayana, 14 (1), h: 172-197

Ervina. 2011. Faktor-faktor yang Mempengaruhi Struktur Modal pada Perusahaan Farmasi dan Kimia yang Terdaftar di Bursa Efek Indonesia Periode 2007- 
2011. Jurnal Jurusan Akuntansi. Universitas Maritim Raja Ali Baji, Tanjungpinang

Hakim, Arief Rahman. 2013. Pengaruh Struktur Aktiva, Profitabilitas, Ukuran Perusahaan dan Likuiditas Terhadap Struktur Modal. Skripsi. Jakarta: UIN Syarif Hidayatullah

Joni dan Lina. 2010. Faktor-faktor yang Mempengaruhi Struktur Modal. Jurnal Bisnis dan Akuntansi, 12 (2), h: 81-96

Lim, Thian Cheng. 2012. Determinants of Capital Structure Empirical Evidence from Financial Services Listed Firm in China. International Journal of Economics and Finance, 4 (3), pp: 191-203

Margaretha, Farah dan Aditya Ramadhan. 2011. Faktor-faktor yang Mempengaruhi Struktur Modal pada Industri Manufaktur di Bursa Efek Indonesia. Jurnal Bisnis dan Akuntansi, 12 (2), h: 119-130

Mustafa, Ali. 2011. The Determinants of Capital Structure of Jordanian Mining and Extraction Industries. European Journal of Economics, Finance \& Administrative Sciences, 2 (9), pp: 156

Myers, Stewart C. 1984. The Capital Structure Puzzle. The Journal of Finance, 39 (3), pp: 575-592

Myers, Stewart C., dan Nicholas S. Majluf. 1984. Corporate Financing and Investment Decisions When Firm Have Information That Investors Do Not Have. Journal of Financial Economics, 1 (3), pp: 187-221

Nadzirah, dkk. 2016. Pengaruh Ukuran Perusahaan dan Profitabilitas Terhadap Struktur Modal. Jurnal Manajemen, 4 (2), Universitas Pendidikan Ganesha

Nanok, Yanuar. 2008. Capital Structure Determinant in Indonesia. Akuntabilitas, 7 (2), pp: 122-127

Putri, Meidera Elsa Dwi. 2012. Pengaruh Profitabilitas, Struktur Aktiva, dan Ukuran Perusahaan Terhadap Struktur Modal pada Perusahaan Manufaktur Sektor Industri Makanan dan Minuman yang Terdaftar di Bursa Efek Indonesia. Jurnal Manajemen, 1 (1), Universitas Negeri Padang

Rafique, Mahira. 2011. Effect of Profitability \& Financial Leverage On Capital Structure: A Case of Pakistan's Automobile Industry. Economic and Finance Review, 1 (4), pp: 50-58 
ISSN: 2302-8556

E-Jurnal Akuntansi Universitas Udayana

Vol.22.3. Maret (2018): 1682-1710

Rajan, Raghuram G., dan Luigi Zingales. 1995. What Do We Know About Capital Structure? Some Evidence from International Data. Journal of Finance, 50 (5), pp: 1421-1460

Riasita, Defia. 2014. Pengaruh Profitabilitas, Likuiditas, Pertumbuhan Aktiva, Struktur Aktiva, dan Ukuran Perusahaan Terhadap Struktur Modal pada Perusahaan Manufaktur di Bursa Efek Indonesia Periode 2009-2013. Skripsi. Yogyakarta: Universitas Negeri Yogyakarta

Saidi. 2004. Faktor-faktor yang Mempengaruhi Struktur Modal pada Perusahaan Manufaktur Go Public di BEJ. Jurnal Bisnis dan Ekonomi, 1 (11), h: 44-58

Salawu, Rafiu S., dan Obafemi Awolowo. 2009. The Effect of Capital Structure on Profitability: An Empirical Analysis of Listed Firms in Nigeria. The International Journal of Business and Finance Research, 3 (2), pp: 121-129

Sayilgan, Guven., Hakan Karabacak, dan Guray Kucukkocao. 2006. The FirmSpecific Determinants of Corporate Capital Structure: Evidence from Turkish Panel Data. Investment Management and Financial Innovations, 3 (3), pp: 125-139

Seftiane dan Ratih Handayani. 2011. Faktor-faktor Yang Mempengaruhi Struktur Modal pada Perusahaan Go Public Sektor Manufaktur. Jurnal Akuntansi dan Bisnis, 13 (1), h: 39-56

Titman, Sheridan dan Roberto Wessels. 1988. The Determinants of Capital Structure Choice. The Journal of Finance, 43 (1), 1-19

Van Horne, James C., dan John M. Wachowicz, Jr. 1998. Prinsip-Prinsip Manajemen Keuangan. Jakarta: Salemba Empat

Wahyuni, Indah A. T., dan Ni Putu S. Suryantini. 2014. Pengaruh Ukuran Perusahaan, Profitabilitas, dan Penghematan Pajak Terhadap Struktur Modal. E-Jurnal Manajemen Universitas Udayana, 3 (5), 1457-1470

Widyaningrum, Yunita. 2015. Pengaruh Profitabilitas, Struktur Aktiva, dan Ukuran Perusahaan Terhadap Struktur Modal Perusahaan. Skripsi. Yogyakarta: Universitas Negeri Yogyakarta 